\title{
BENTHIC AND PERIPHYTIC INVERTEBRATE CONTOUR GROUPS IN TECHNO-ECOSYSTEMS OF POWER PLANTS OF UKRAINE
}

\author{
A. Protasov, A. Sylaieva, T. Novoselova, I. Morozovskaya \\ Institute of Hydrobiology NAS of Ukraine, Kyiv, Ukraine \\ e-mail: labtech-hb@ukr.net
}

\begin{abstract}
Based on many years of research experience of water techno-ecosystems of thermal and nuclear power plants a brief review of the main patterns of formation of the composition, cenotic structure, elements of the functional organization of benthos and periphyton communities was made. It was shown that the composition of zoobenthos and zooperiphyton in some cooling ponds, other technical water bodies and watercourses was quite rich. In addition, due to the rather intensive invasive process, the list of taxa is constantly expanding. Species of tropical and subtropical origin have been recorded. Of particular importance is the invasion of species that may be the cause of bio-hindrances in the operation of power plant equipment. Techno-ecosystems have been studied to varying degrees. One of the most studied for a long time are the cooling ponds of Khmelnitsky and Chernobyl nuclear power plants. Hydrobiological research and monitoring at the first one has been carried out for more than 20 years. It was found that the influence of biotic invasion (invasion of Dreissenidae) may have a significant impact, comparable to extreme technogenic factors, on both the ecosystem and technical water supply facilities. The stages of contourisation and decontourisation processes in the Khmelnitsky NPP techno-ecosystem were established. At the Chernobyl NPP cooling pond, studies were carried out during all periods of the existence of the reservoir and the power plant, until the process of uncontrolled pond descent and transforming it into a unique wetland. Based on the obtained data, practical recommendations relating to the organization of hydrobiological and environmental monitoring, as well as reducing biological hindrances and improving the reliability of power plant equipment have been developed.
\end{abstract}

\section{Introduction}

A feature of water techno-ecosystems is their dependence on the regime of technogenic impact, the predominance of technogenic factors, technogenic properties of biotopes, this complex of factors and conditions also determines the characteristics of ecological processes. Research of power plants techno-ecosystems of Ukraine showed successional processes occurring in cooling ponds (CP) and other water bodies are violated by both technogenic and biotic (invasions) factors and have not sustained, but rather, pulsating character (Hydrobiology.., 1991; NPP techno-ecosystem..., 2011).

The increased interest in the study of the hydrobiological regime of cooling ponds was associated with the beginning of the active construction of power plants (1960-1970s). At present, studies of technoecosystems of power plants have undergone certain transformations, both in direction and in scale (Protasov, 2021).

The aim of this study was to summarize the available long-term research material of important components of ecosystems of technical water bodies, contour groupings - zoobenthos and zooperiphyton.

\section{Materials and methods}

The studies were carried out at the operating CPs of Ukraine - Khmelnytsky (KhNPP), Zaporozhye (ZNPP), South-Ukrainian (SUNPP), at the CP of large thermal power plants - 
Krivrozhskaya, Zmievskaya, etc., as well as at the CP of the Chernobyl NPP (ChNPP), the CP of which in 2014-2018 was drained and transformed into a technogenic wetland. The generally accepted research methods of invertebrates were used, as well underwater research were conducted. Archival materials, own hydrobiological database were used. The characteristics of some of the studied techno-ecosystems are presented in the table 1.

Table 1. Characteristics of techno-ecosystems of Ukrainian NPPs

\begin{tabular}{|l|c|c|c|c|l|}
\hline $\begin{array}{c}\text { Techno- } \\
\text { ecosystems }\end{array}$ & $\begin{array}{c}\text { CP area, } \\
\mathrm{km}^{2}\end{array}$ & $\begin{array}{c}\text { CP volume, } \\
\mathrm{mln} . \mathrm{m}^{3}\end{array}$ & $\begin{array}{c}\text { Maximum tem- } \\
\text { perature, }{ }^{\circ} \mathrm{C}^{*}\end{array}$ & $\begin{array}{c}\text { Average } \\
\text { depth, } \mathrm{m}\end{array}$ & $\begin{array}{c}\text { Typical solid } \\
\text { substrates }\end{array}$ \\
\hline KhNPP & 20 & 120 & 36 & 6,0 & concrete \\
\hline ZNPP & 8,2 & 47 & 37 & 5,7 & stone dump \\
\hline SUNPP & 8,6 & 86 & 41 & 10,0 & stone dump \\
\hline ChNPP & 21,7 & 149 & 36 & 6,9 & $\begin{array}{l}\text { stone dump, } \\
\text { concrete** }\end{array}$ \\
\hline
\end{tabular}

* Noted in the study period. ** before the descent

\section{Results and discussions}

Changes in the composition of invertebrate communities, their abundance, the structure of dominance are determined by factors of technogenic and biotic nature. Great importance is the nature and mode of operation of TPPs and NPPs. Among the technogenic factors in techno-ecosystems, the temperature factor is the most significant. The most intense thermal regime observed in CP ZNPP and SUNPP, summer temperature was more then $41^{\circ} \mathrm{C}$ at the area of discharge water.

It should be noted quite high richness of contour groupings of tehno-ekosistems - over the period of many years of research, about 300 taxa of invertebrates were recorded (Protasov, Silaeva, 2012). Most of them were found in both benthos and periphyton communities. Sedentary invertebrates such as Spogia, Bryozoa, Enthoprocta, Coelenterata can be distinguished as specific for periphyton. However, this specificity is pretty relative (Protasov, 2011), and «typical» periphyton organisms were often found in benthic samples they settle on the shells of mollusks, random solid substrata.

With a significant and permanent technogenic impact, the degradation of the bottom communities occurs, at the same time, a low level of development of invertebrates can be maintained for a significant period of time, the ecosystem goes into a «pseudo-climax» state. So, in the first year after filling the SUNPP CP (1980), dramatic change in conditions (from a small river to a cooling pond) led to a decrease in richness - from 14 (in Tashlyk river) to 2. In three to four years Hydra sp., Nematoda, Amphipoda, Cumacea, Odonata, Ephemeroptera, Triphoptera, Ceratopogonidae were noted in the reservoir (upper reaches), D. polymorpha was ubiquitous. In 1986, 48 taxa from 15 groups were recorded in the zoobenthos (Novoselova et al., 2020). After a significant summer temperature increase in 1986, the species composition of zoobenthos sharply decreased (7 taxa - in 1988, up to 12-13 taxa in 1989-1992). After com- 
plete elimination (not registered in 1988) Dreissena was recorded locally in 1989-1992, but since 1997 it has completely disappeared. From this period to the present, the zoobenthos of the CP was extremely poor (9-15 taxa).

Oligochetes Limnodrilus claparedeanus Ratzel, и L. hoffmaisteri Claparede, Leptochironomus tener (Kieffer) were the most tolerant to the effect of temperature in zoobenthos, these species inhabit areas of the SUNPP CP with high heating.

Taxonomic richness of zoobenthos of ZNPP CP also was low- from 10-11 (1995) to 29 taxa (in 2017). Hydra sp., Nematoda, Oligochaeta, Hirudinea sp., Ostracoda gen. sp., Trichoptera, Chironomidae, Gamamridae, Ephemeroptera, Gastropoda were noted.

Taxonomic distribution was heterogeneous - intake (IC) and discharge (DC) channels differed by a specific taxonomic composition relative to the CP. For example, Branchiura sowerbii Beddard and Psectrocladius dilatatus Wulp were recorded only in IC of ZNPP.

In taxonomic terms, the zoobenthos of CP of KhNPP is one of the richest from another CP. During the observation period (mostly summer and early autumn seasons of research 1998-2019) in the zoobenthos of CP of KhNPP 177 taxa of invertebrates from 24 groups were recorded.

During the first period of research (when only one NPP unit was in operation) 87 taxa (from 30 to 61 taxa for separate seasons and years) were found in zoobenthos (NPP techno-ecosystem..., 2011). In the second period (2005-2010), after the D. polymorpha invasion, the total number of benthic taxa increased to 128 taxa (from 42 to 82 taxa), and during the third period (2012-2019) after the invasion of D. bugensis, in general, remained at a close level - 117 taxa (from 40 to 76 taxa for certain years). The taxonomic composition of zoobenthos over the study periods was similar.

Unstable water level in CP when the water level declines, it leads to the formation of vast shallow waters, which determined the increase in the total richness of benthos due to insects. They are mainly represented by psammophilic and near-water invertebrates (Simuliidae sp., Pseudosmittia sp., Tabanidae sp., Tipulidae sp., Dolichopodidae sp., Stratiomyidae sp., Psychomyiidae sp., Haliplidae sp.). KhNPP CP is only one in Ukraine, in which Gammaridae were absent.

In the taxonomic composition of zoobenthos and zooperiphyton Chironomidae and Oligochaeta were dominated. Thus, in the KhNPP CP their share in the total number of taxa of zoobenthos was $24-42$ and $22-33 \%$ respectively.

Long-term studies of zooperiphyton in the KhNPP techno-ecosystem have shown both taxonomic richness one and benthos was similar. It was quite high, in the first (1998-2001) - 69 taxa and the second period (2005-2012) - 95 taxa. The total list of zooperiphyton taxa in KhNPP CP included 125 taxa (NPP techno-ecosystem..., 2011). In the third period (2012-2019), after the invasion of $D$. bugensis and a decrease in the abundance of $D$. polymorpha, the number of periphitic taxa decreased, from 40 in D. bugensis communities (2013) to 8 taxa (2013 and 2015) in D. bugensis and E. carteri communities.

Techno-ecosystems undergo significant, often unpredictable, anthropogenic influences, 
leading radical changes in ecosystems. Thus, with an uncontrolled descent of the $\mathrm{CP}$ of $\mathrm{ChN}$ PP the species composition of the zoobenthos, like the periphyton, has undergone significant changes. During the operation period 1979-1986 more then 70 species of invertebrates were registered in the contour subsystem. After stop of NPP work removal of technogenic load led to a significant increase in taxonomic richness (in 2002 was noted 143 taxa). In the period 20122013, before the descent of the CP, there were 95 taxa invertebrates in the contour subsystem. No significant changes in the taxonomic composition of invertebrates during the descent period (2016-2018) were recorded - there were 118 taxa in zoobenthos and 85 in zooperiphyton. The dominance of oligochaetes and chironomid larvae was note. By the autumn of 2018 the low water level in the former CP has stabilized, now the CP is a complex of separate floodplain-type water bodies. The elimination of Dreissenidae from benthic groups led to a reduction in the total number of species and the almost complete disappearance of Amphipoda. With a decrease in the water level, the number of non-living substrates for the development of invertebrates of zooperiphyton significantly decreased, substrates were found extremely mosaic and in insignificant quantities. However, such changes significantly did not affect the taxonomic richness of the zooperiphyton.

Very important phenomenon in technoecosystems is invasive process. The invasion of alien species is important, in this case, in two aspects. Firstly, cooling ponds may cause further invasions. Alien species are resistant to adverse conditions, in particular, the temperature factor. CPs are refugia for the alien species. Secondly, invaders, as a rule, act as significant agents of biological hindrances. The invasive process was observed in all studied techno-ecosystems. In CP of KhNPP new invasive species from different taxonomic groups of invertebrates are constantly recorded. Invaders are different, including tropical origin: Eunapius carteri (Bowerbank) (since 2013), Bratislavia daday (Michaelsen) (since 2013), Stenocypris sp. (since 2018), Limnomysis benedeni Czerniavsky (since 2012), Corophium robustum G.O.S. (since 2019), Dreissena polymorpha Pall. (since 2003), D. bugensis Andr. (since 2012), Ferrissia sp. (since 2008). Most of them have naturalized. Bat, some species were registered in CP only once and have not met again, for example Tyrrhenocythere amnicola donetziensis (Dubowsky), Theodoxus euxinus (Clessin), Planorbella sp.

Abundance of contour hydrobionts was very different. In CP of ZNPP in 1995 and 2011, the abundance indicators were at the level of 67-7450 ind. $/ \mathrm{m}^{2}$, biomass $-0,004-2,68 \mathrm{~g} / \mathrm{m}^{2}$, with the dominance of oligochaetes and chironomid larvae. The invasion of subtropical Gastropoda Melanoides tuberculata (Müller) and Terebia granifera (Lamarck) into techno-ecosystem determined biomass increase on average up to $44,06 \mathrm{~g} / \mathrm{m}^{2}$ (maximum to $180,10 \mathrm{~g} / \mathrm{m} 2$ ).

In the SUNPP CP, a significant increase in biomass (up to $350 \mathrm{~g} / \mathrm{m}^{2}$ ) occurred after the invasion of $M$. tuberculata in this water body. In the first years of its existence (1985-1986), a community with the dominance of $D$. polymorpha and a biomass of about $300 \mathrm{~g} / \mathrm{m}^{2}$ has formed in the benthos. But with a constant high thermal effect, the zebra mussel has eliminated. Communities with low biomass (near $1 \mathrm{~g} / \mathrm{m}^{2}$ ) which existed for over a decade have formed.

In the CP of KhNPP in the first period, the indices of zoobenthos abundance were within 
5,2-9,1 thousand ind./m2 and 5,45-471,25 $\mathrm{g} / \mathrm{m}^{2}$ (including large bivalve molluscs that lived in local areas), dominated by oligochaetes and chironomid larvae. After the invasion of D. polymorpha, the numbers increased on average to 21,0 thousand ind. $/ \mathrm{m}^{2}$, total biomass increased on average for CP to $1,1-2,9 \mathrm{~kg} / \mathrm{m}^{2}$ and this level was observed until 2010 . The maximum biomass of zoobenthos in the local area was $25,7 \mathrm{~kg} / \mathrm{m}^{2}$. During the third period, the biomass is in the range of $13,06-697,82 \mathrm{~g} / \mathrm{m}^{2}$.

In the first period (1998-2001), the indices of the numbers of zooperiphyton in the reservoir ranged from 93 (depth 2-3 m) to 129000 ind./ $\mathrm{m}^{2}$ (depth 0,4-0,5 m). Almost at all investigated stations, there was a well-pronounced trend to decrease in numbers with depth.

In the second period (2004-2012), after the introduction of D. polymorpha, a spatial displacement of the maximum abundance from area at the water's edge into the depth have occurred. Biomass has increased by 3 orders (Protasov, Silaeva, 2012). If at a depth of 4-5 $\mathrm{m}$ in 2005 at the dam the biomass was $14,1 \mathrm{~kg} / \mathrm{m}^{2}$ and in the intake channel $-19,7 \mathrm{~kg} / \mathrm{m}^{2}$, then in 2009 the biomass of zooperiphyton decreased to $2-6 \mathrm{~kg} / \mathrm{m}^{2}$.

The third period (2012-2019) was associated with the invasion of the second species of Dreissena - D. Bugensis into the reservoir. In 2012, the numbers of zooperiphyton decreased with depth (123056 ind. $/ \mathrm{m}^{2}$ at a depth of $0,5 \mathrm{~m}$ to $13800 \mathrm{ind} . / \mathrm{m}^{2}$ at $6,0 \mathrm{~m}$ ). The biomass in the intake channel was the largest at $5 \mathrm{~m}$, (the share of Dreissena was $97.0 \%$ ) and exceeded $100 \mathrm{~g}$ / $\mathrm{m}^{2}$. From 2014 to 2016 indices of the periphyton abundance in the IC and at the dam decreased (IC - 3835,4-1024,4 g/m²) and on the dam 711,2 $\mathrm{g} / \mathrm{m}^{2}$ (2015) to 1,63 $\mathrm{g} / \mathrm{m}^{2}$ (2017).

At present, populations of two species of Dreissena coexist in the KhNPP cooling pond, with D. bugensis prevailing in the periphyton.

Studies have shown a significant role in techno-ecosystems, in addition to technogenic factors, biotic factors also play a role. Thus, the invasion of Dreissena into the CP of KhNPP in the contour subsystem led to the formation of spatially complex of consortium-type communities with high biomass, relatively stable over of years. However, with long-term observation it was found that the period of stability continued for relatively short time (figure). In the main technogenic biotopes - at the dam and in the intake channel - the distribution of Dreissena in depth was characterized by an increase in biomass by $4-6 \mathrm{~m}$. Therefore, we present the average values of the zebra mussel biomass at these depths.

And in CP ChNPP the development of Dreissenidae determined the quantitative indices of the invertebrates of the contour subsystem.In the period before the descent (2012-2013), the level of zooperiphion development in the CP of ChNPP was high - 11,70-190,3 thousand ind. $/ \mathrm{m}^{2}$ and $1,29-17,78 \mathrm{~kg} / \mathrm{m}^{2}$. In 2012-2013, the quantitative indicators of benthos were 96057480 ind. $/ \mathrm{m}^{2}, 0,43-9148,52 \mathrm{~g} / \mathrm{m}^{2}$ (biomass without molluscs $0,43-50,37 \mathrm{~g} / \mathrm{m}^{2}$ ). The biomass in the contour subsystem was determined by D. bugensis, which invited into the water body in the 1990.

Fast draining of the CP stone dump during the descent led to the fast decline in the total stock of zooperiphyton. The biomass of the zooperiphyton in 2016-2017 decreased by 2 times in comparison with the period before descent, and by 2018 - decreased by almost an order 
of magnitude (relative to 2016-2017). Reducing in the abundance of zoobenthos during the descent (2016-2018) occurred relatively gradually. Only by 2018 elimination of dreissenids determined a significant decrease in the abundance of zoobenthos - numbers tripled, biomass - in 122 times.

Thus, the cardinal transformation of the technogenic reservoir led to a decrease in the quantitative indicators of the invertebrates of the contour subsystem.

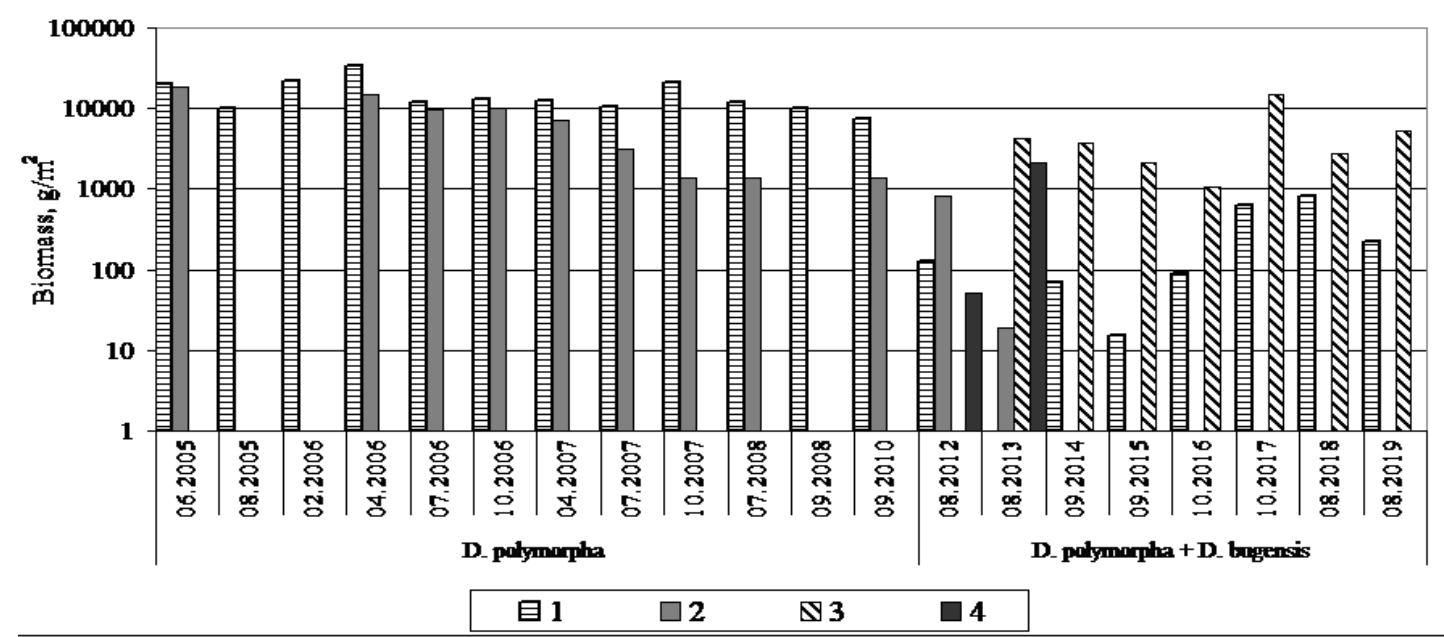

Figure 1. Dynamics of Dreissenidae biomass in the techno-ecosystem KhNPP: 1 - D. polymorpha in IC, 2 - D. polymorpha on the dam, 3 - D. bugensis in IC, 4 - D. bugensis on the dam.

The average values at a depth of 4-6 $\mathrm{m}$ are presented

It is possible to conclude the richness of invertebrate of contour groups in techno-ecosystems is quite large. At the early stages of research of cooling ponds, it was supposed that the fauna in them should be poor (Ecology..., 1975). In the CP, there is a constant invasive process, which replenishes the composition of groups. In the investigated techno-ecosystems, an increase in the number of taxa and quantitative indicators of invertebrates was associated with the invasion of $D$. polymorpha. However, during the invasion of the second species of Dreissenids (D. bugensis) in the CP of KhNPP, neither an increase in richness nor indicators of abundance was noted. At the same time, the second species took a dominant position in biomass, this phenomenon was also noted in the ChNPP CP (Model groups..., 2002).

Filtration activity of Dreissena caused the transformation of the entire ecosystem of the KhNPP CP due to contouring processes (NPP techno-ecosystem..., 2011; Protasov et al., 2021). With the influence of Dreissena increases, in phytoplankton the dominants and the structure of dominance changed, the indices of abundance and taxonomic richness decreased to their minimum values at the peak of contouring. After reducing the impact and adaptation processes in the ecosystem there was an increase in the quantitative indicators and richness of phytoplankton. The reduction of individual phylums of algae in the phytoplankton composition proceeded in the reverse sequence with respect to their disappearance under the pressure of Dreissena.

Further studies of the contour groupings of techno-ecosystems should be carried out in 
the following directions - study of the taxonomic composition, especially of such groups as Oligochaetes, Chironomid larvae. It is important to study the invasive process, since CPs can be refugia of the distribution of invasive species into natural water bodies. Particular attention should be paid to contour groupings in terms of their ability to create biological hindrances in technical water supply systems.

Our long-term studies show for practical purposes, a modern system of hydrobiological monitoring should be created in techno ecosystems.

\section{Bibliography}

1. Ecology of organisms in cooling ponds. Proceed. of the Institute of Biology of Inland Waters. 1975. Iss. 27 (30). 292 p. (In Russian).

2. Hydrobiology of cooling ponds of thermal and nuclear power plants in Ukraine. Kyiv: Nauk. Dumka, 1991. 192 p. (In Russian).

3. Model groups of invertebrates as indicators of radioactive pollution of ecosystems. Kyiv: Phytosocialcenter, 2002. 204 p. (In Russian).

4. Novoselova T.N., Silaeva A.A., Gromova Yu.F., Menshova T.I., Morozovskaya I.A., Protasov A.A. Technoecosystem of the cooling pond of the South-Ukrainian NPP: dynamics of groupings and their transformation. Ecosystem transformation. 2020. Vol. 3, N 1. P. 101-116.

5. NPP techno-ecosystem. Hydrobiology, abiotic factors, environmental assessments. Kyiv, 2011. 234 p. (in Russian).

6. Protasov A.A. Life in the hydrosphere. Essays on General Hydrobiology. 2011. Kyiv: Akademperiodika. 704 p. (In Russian).

7. Protasov A.A. Paradigm shift in technical hydrobiology: from local impact, to a new techno-ecosystem concept for thermal and nuclear plant water. Ecosystem Transformation 2021. Vol. 4 (1). P. 3-9. https://doi.org/10.23859/estr-201022

8. Protasov A., Novoselova T., Uzunov Y., Barinova S., Sylaieva A. Changes in the Planktonic System of the Nuclear Power Plant Cooling Pond Related to the Invasion of Dreissenidae (Mollusca: Bivalvia). Acta Zool. Bulg. Publ. online 12 May 2021 http://www.acta-zoologica-bulgarica.eu/2021/002433

9. Protasov A.A., Silaeva A.A. Contour groups of hydrobionts in the techno-ecosystems of TPPs and NPPs. Kyiv, 2012. 274 p. (In Russian). 